PNL-8834

UC-310

\title{
Impact Evaluation of Lighting Retrofit Projects at Boeing Commercial Airplane Group Under The Energy \$avings Plan
}

\author{
G. P. Sullivan \\ M. A. Oens \\ G. E. Spanner
}

January 1994

Prepared for Sheila Riewer

Program Evaluation Section

Office of Energy Resources

Bonneville Power Administration

U.S. Department of Energy

under Contract DE-AC06-76RLO 1830

Pacific Northwest Laboratory

Richland, Washington 99352 


\section{DISCLAIMER}

This report was prepared as an account of work sponsored by an agency of the United States Government. Neither the United States Government nor any agency thereof, nor Battelle Memorial Institute, nor any of their employees, makes any warranty, expressed or implied, or assumes any legal liability or responsibility for the accuracy, completeness, or usefulness of any information, apparatus, product, or process disclosed, or represents that its use would not infringe privately owned rights. Reference herein to any specific commercial product, process, or service by trade name, trademark, manufacturer, or otherwise does not necessarily constitute or imply its endorsement, recommendation, or favoring by the United States Government or any agency thereof; or Battelle Memorial Institute. The views and opinions of authors expressed herein do not necessarily state or reflect those of the United States Government or any agency thereof.

\section{PACIFIC NORTHWEST LABORATORY}

operated by

BATTELLE MEMORIAL INSTITUTE

for the

UNITED STATES DEPARTMENT OF ENERGY

under Contract DE-AC.06-76RLO 1830 


\section{Summary}

This impact evaluation of two lighting retrofit projects that were recently installed at Boeing Commercial Airplane Group (Boeing) was conducted for the Bonneville Power Administration (Bonneville) as part of an evaluation of its Energy \$avings Plan (E\$P) Program. The first project was a light-fixture and lighting control retrofit, consisting of five individual measures installed in Building 40-05. The second project was a retrofit of all parking lot lighting on the site. The objective of this impact evaluation was to assess how much electrical energy is being saved at Boeing as a result of the E\$P projects and to determine how much the savings cost Bonneville and the region. The impact of the project was evaluated with a combination of engineering analysis, financial analysis, interviews, and submittal reviews (Boeing's proposals and completion reports).

Based on this impact evaluation, energy savings from the Building 40-05 and the parking lot lighting projects are expected to be $1,523,386 \mathrm{kWh} / \mathrm{yr}$ and $578,160 \mathrm{kWh} / \mathrm{yr}$, respectively. The combined savings is $2,101,546 \mathrm{kWh} / \mathrm{yr}$ (0.24 average megawatts). The Building $40-05$ project cost $\$ 85,512$ to install, and Boeing received payment of $\$ 64,996$ (in 1993 dollars) from Bonneville for acquisition of the energy savings. The parking lot project cost $\$ 202,000$ to install $(\$ 9,000$ more than the cost listed in the completion report), and Boeing received $\$ 75,849$ (in 1993 dollars) from Bonneville. The real levelized cost of these energy savings to Bonneville are $4.1 \mathrm{mills} / \mathrm{kWh}$ for the Building 40-05 project and 12.5 mills $/ \mathrm{kWh}$ for the parking lot project, assuming a 15 -year project life. The combined real levelized energy cost to Bonneville is $6.4 \mathrm{mills} / \mathrm{kWh}$. The real levelized cost to the region fo: the Building 40-05 project, the parking lot project, and the combined cost to Bonneville are $8.0 \mathrm{mills} / \mathrm{kWh}$, $48.0 \mathrm{mills} / \mathrm{kWh}$, and $19.0 \mathrm{mills} / \mathrm{kWh}$, respectively. All of these costs are in 1993 dollars and do not include transmission and distribution effects.

Based on the project installation costs and energy savings benefits, neither of these projects would have been implemented by Boeing without the E\$P acquisition payment. 


\section{Contents}

Summary $\ldots \ldots \ldots \ldots \ldots \ldots \ldots \ldots \ldots \ldots \ldots \ldots \ldots \ldots \ldots \ldots$

1.0 Introduction $\ldots \ldots \ldots \ldots \ldots \ldots \ldots \ldots \ldots \ldots \ldots \ldots \ldots \ldots \ldots$

1.1 Approach for Impact Evaluation $\ldots \ldots \ldots \ldots \ldots \ldots \ldots$

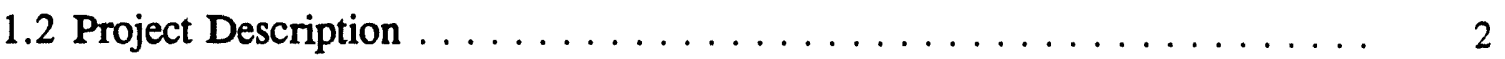

1.3 Summary of Project Impacts $\ldots \ldots \ldots \ldots \ldots \ldots \ldots \ldots$

2.0 Impact Evaluation $\ldots \ldots \ldots \ldots \ldots \ldots \ldots \ldots \ldots \ldots$

2.1 Energy Savings and Fuel Switching $\ldots \ldots \ldots \ldots \ldots \ldots$

2.2 Impacts to the Firm $\ldots \ldots \ldots \ldots \ldots \ldots \ldots$

2.3 Impacts to the Utility $\ldots \ldots \ldots \ldots \ldots \ldots \ldots \ldots \ldots \ldots \ldots \ldots$

2.4 Real Levelized Costs $\ldots \ldots \ldots \ldots \ldots \ldots \ldots \ldots$

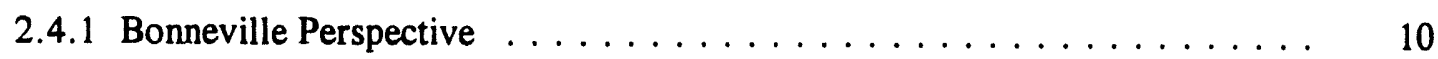

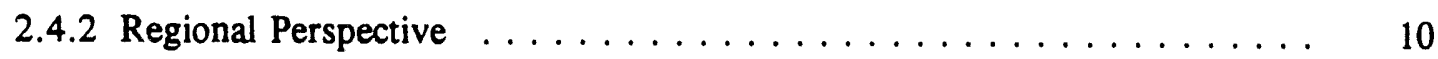

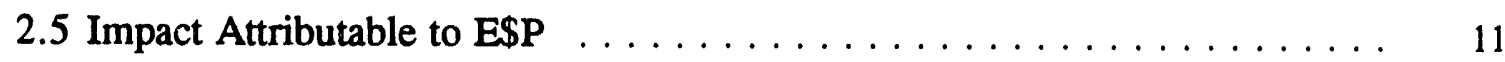

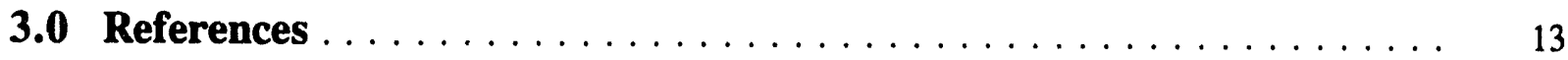

Appendix A - Financial Evaluation Details $\ldots \ldots \ldots \ldots \ldots \ldots \ldots$

Appendix B - Cover Sheets from Boeing's Project Proposals $\ldots \ldots \ldots$. . . . . B.1 


\section{Tables}

1.1 Levelized Energy Cost $\ldots \ldots \ldots \ldots \ldots \ldots \ldots \ldots \ldots \ldots \ldots \ldots$

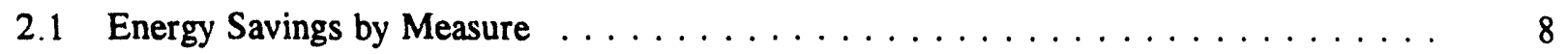

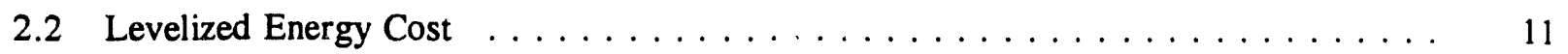




\subsection{Introduction}

This report describes Pacific Northwest Laboratory's (PNL's)(a) evaluation of the impact of two separate energy conservation projects installed in November, 1992 at Boeing Commercial Airplane Group (Boeing) in Everett, Washington. The projects at Boeing are two in a continuing series of industrial energy conservation projects to have their impact evaluated by PNL. All of the projects have received or will receive acquisition payments from the Bonneville Power Administration (Bonneville) under the Energy \$avings Plan (E\$P) Program.

The E\$P is being offered to reduce electrical energy consumption in the industrial sector of Bonneville's service territory. For these Boeing projects, the acquisition payment offered under the program was equal to the lesser of $15 \mathrm{c} /$ kilowatt-hour $(\mathrm{kWh})$ saved in the first year or $80 \%$ of eligible project costs.

The general objective of the impact evaluation was to determine how much electrical energy is saved by the projects and at what cost to Bonneville and to the region. In support of this general objective, answers were sought to the following questions:

1. How much electrical energy is saved annually by the energy conservation projects in terms of kilowatt-hours, kilowatt-hours per unit of plant output (unit savings), and average megawatts (aMW)? Also, did any fuel switching result from implementing these projects?

2. If the projects improved the productivity of the process, did the firm then increase output of the process to take advantage of the productivity improvement? Did the change in output result in a net increase or decrease in energy used by the process? Did the change in output cause changes in output at the firm's other plants in the region?

3. What was the net impact to the serving utility in terms of electrical energy consumption (in kilowatt-hours) from implementing these projects?

4. What are the real levelized costs of the projects from the perspectives of Bonneville and the region?

5. How much of the projects' impact can be attributed to the E\$P?

(a) Pacific Northwest Laboratory is operated for the U.S. Department of Energy by Battelle Memorial Institute under Contract DE-AC06-76RLO 1830. 


\subsection{Approach for Impact Evaluation}

Before selecting individual energy conservation projects for evaluation, PNL developed a general impact evaluation methodology (Spanner et al. 1988). The major finding of the methodology development was that in the industrial sector, energy conservation projects must be evaluated on a case-by-case basis. Accordingly, the general methodology consists of a variety of impact evaluation techniques that can be applied to individual projects according to the specific circumstances.

'To evaluate the impact of two different lighting projects at Boeing, four techniques were selected from the general methodology: engineering analysis, financial analysis (see Appendix A), site visit and interview, and review of Boeing's submittals.

Representatives from PNL visited Boeing on June 10, 1993, to view the projects firsthand and to interview the project manager.

\subsection{Project Description}

Boeing's Everett, Washington, site consists of office buildings, warehouses, hangars, and aircraft assembly buildings. Boeing manufactures its $747^{\circ}$ and $767^{\circ}$ commercial jetliners at this site. The two projects installed affected Building 40-05 (a light manufacturing and office building) and parking lot lighting at the Everett site.

The project installed in Building 40-05 consisted of the following five measures:

1. In the warehouse/production area, lighting controls were installed to reduce on-time of 646 four-hundred watt, metal halide fixtures from 168 hours/week to 108 hours/week.

2. In the office area, 142 thirty-four watt, 3 lamp fluorescent fixtures with energy efficient ballasts were replaced with 140 thirty-two watt, 1 lamp fluorescent fixtures using 1 electronic ballast for every 3 fixtures.

3. Also in the office area, lighting controls were installed to reduce on-time of the new 140 thirtytwo watt fluorescent fixtures from 168 hours/week to 80 hours/week. 
4. In the restroom and cafeteria area, 93 eight-two watt fixtures with 2 fluorescent lamps and standard ballasts were retrofitted with 57 fifty-seven watt fixtures and 36 sixty-two watt fixtures with 2 fluorescent lamps and 1 electronic ballast for every 2 fixtures.

5. Also in the restroom and cafeteria area, lighting controls were installed to reduce on-time of the new 93 thirty-two watt fluorescent fixtures from 168 hours/week to 80 hours/week.

The second project involved upgrading the parking lot lighting. This consisted of replacing 25 two-lamp and 58 four-lamp (both using 1,000 watts/lamp) fixtures with 83 four-lamp (400 watts/lamp) high pressure sodium fixtures. All of these fixtures are controlled by photocells.

The energy savings from these projects resulted from the installation of high-efficiency light fixtures and lighting controls to shut off lights during unoccupied or daytime hours. In its completion report for the Building 40-05 project, Boeing made no mention of attempting to calculate or take credit for the interactive effects that lighting has on heating and cooling loads.

Boeing submitted four documents to Bonneville, including a proposal and a completion report for each project. The proposals described the energy conservation projects and presented Boeing's cost and benefit expectations. Included were calculations of the project's expected simple payback. The completion reports were submitted to Bonneville after the projects were installed and Snohomish County Public Utility District had verified the resulting energy savings. These documents listed the actual costs of the projects as well as a calculation of the energy savings that had been achieved. Copies of the cover sheets from the project proposals are included in Appendix B.

The total cost to Boeing for these projects was $\$ 287,512$ ( $\$ 85,512$ for the Building $40-05$ project and $\$ 202,000$ for the parking lot project). The parking lot cost of $\$ 202,000$ reflects an additional $\$ 9,000$ over the cost in the completion report. This cost was reported by Boeing to PNL during the evaluation site visit and was considered as part of the project's total installed cost in calculating the levelized energy cost.

For the energy savings, Bonneville paid Boeing $\$ 64,996$ for the Building $40-05$ project and $\$ 75,849$ for the parking lot project. The acquisition payments made for both projects were calculated by multiplying the verified energy savings from the completion reports (in $\mathrm{kWh}$ ) by $\$ 0.15 / \mathrm{kWh}$ saved and then by 0.95 for contractor cost share. An error was noted in the energy savings calculation for the parking lot project. A transposition of numbers, $532,276 \mathrm{kWh} / \mathrm{yr}$ saved instead of the correct value of $523,276 \mathrm{kWh} / \mathrm{yr}$ saved, was used in the acquisition payment calculation. The correct acquisition payment should have been $\$ 74,567$ instead of $\$ 75,849$. 


\subsection{Summary of Project Impacts}

According to analysis carried out for this impact evaluation, the Building 40-05 and parking lot projects are expected to save $1,523,286 \mathrm{kWh} / \mathrm{yr}$ and $578,160 \mathrm{kWh} / \mathrm{yr}$, respectively, for a combined savings of 2,101,546 kWh/yr (0.24 aMW). Over the assumed 15-year life of these projects, levelized costs to Bonneville are $4.1 \mathrm{mills} / \mathrm{kWh}$ ( 1 mill $=1 / 1,000$ of a dollar) for the Building 40-05 project and $12.5 \mathrm{mills} / \mathrm{kWh}$ for the parking lot project. The combined levelized cost to Bonneville is 6.4 mills/ $\mathrm{kWh}$. The levelized costs to the region are $8.0 \mathrm{mills} / \mathrm{kWh}$ and $48.0 \mathrm{mills} / \mathrm{kWh}$ for the Building $40-05$ and parking lot projects, respectively. The combined levelized cost to the region is $19.0 \mathrm{mills} / \mathrm{kWh}$. All these costs are in real 1993 dollars and do not include additional savings that accrue if transmission and distribution losses are considered. The levelized costs to Bonneville, including transmission and distribution losses, for the Building 40-05 project, the parking lot project, and the combined cost are $3.8 \mathrm{mills} / \mathrm{kWh}, 11.6 \mathrm{mills} / \mathrm{kWh}$, and $6.0 \mathrm{mills} / \mathrm{kWh}$, respectively. The levelized costs to the region (including transmission and distribution) for the Building 40-05, the parking lot project, and the combined cost are $7.4 \mathrm{mills} / \mathrm{kWh}, 44.7 \mathrm{mills} / \mathrm{kWh}$, and $17.7 \mathrm{mills} / \mathrm{kWh}$, respectively. Table $1.1 \mathrm{sum}-$ marizes the results of the levelized cost calculations.

Table 1.1. Levelized Energy Cost (1993 mills/kWh)

\begin{tabular}{|l|c|c|c||}
\hline & Building 40-05 & Parking Lot & Combined \\
\hline Bonneville & 4.1 & 12.5 & 6.4 \\
Regional & 8.0 & 48.0 & 19.0 \\
Bonneville with trans./dist. & 3.8 & 11.6 & 6.0 \\
Regicnal with trans./dist. & 7.4 & 44.7 & 17.7 \\
\hline
\end{tabular}

These projects did not meet Boeing's funding criteria based on expected energy savings benefits alone. However, the projects did meet the criteria with the acquisition payment and the expected energy savings. Therefore, we conclude that the two projects would not have been installed without the E\$P. 


\subsection{Impact Evaluation}

The following section addresses the five major objectives of the impact evaluation, as previously stated in Section 1.0.

\subsection{Energy Savings and Fuel Switching}

How much electrical energy is saved annually by the projects in terms of kilowatt-hours, kilowatt-hours per unit of plant output, and average megawatts? Also, did any fuel switching result from implementing these projects?

\section{Energy Savings}

To verify energy savings for these two projects, site inspections were conducted by Bonneville personnel to confirm the number, type, control settings, and proper operation of all installed equipment. Engineering calculations were performed to verify kilowatt-hour savings using hours of operation from the project proposal and the difference between existing and retrofit energy consumption.

Through discussions with Boeing personnel and equipment manufacturers, PNL learned more detailed information regarding annual operating hours for two of the measures in these projects. First, Boeing originally estimated that with the warehouse/production area lighting controls installed, lighting hours of operation could be reduced from 168 to 108 hours/week. However, after the controls were installed, Boeing personnel realized that a further reduction to 80 hours/week could be achieved. This reduction in operating hours increases the estimated energy savings from $929,155 \mathrm{kWh} / \mathrm{yr}$ to $1,362,760 \mathrm{kWh} / \mathrm{yr}$, a $47 \%$ increase in estimated savings for this measure.

Secondly, after discussions with exterior area lighting manufacturers, PNL learned that average annual operating hours for photocell-controlled lighting (such as Boeing's parking lot lighting project evaluated in this report) are approximately 4,000 hours/yr. This is an increase in annual operating hours over the amount found in the project proposal, for both the before- and after-measure cases, which results in an increase in the estimated energy savings. The energy savings number reported in the project proposal is $532,276 \mathrm{kWh} / \mathrm{yr}$ and the updated number is $578,160 \mathrm{kWh} / \mathrm{yr}$, which represents about a $9 \%$ increase in savings. 
All other numbers used for estimated energy savings (listed in Table 2.1) in these two projects were from the completion reports. These numbers were verified by PNL and represent accurate estimates of energy savings.

The sum of the energy savings estimates for these two projects was revised from $1,662,057 \mathrm{kWh} / \mathrm{yr}$, as reported in the completion reports, to $2,101,546 \mathrm{kWh} / \mathrm{yr}(0.24 \mathrm{aMW})$.

Table 2.1 summarizes the energy savings by measure taken from the completion reports and from this impact evaluation for the two projects.

\section{Fuel Switching}

Because this project consisted of installing lighting and lighting controls, fuel switching was not an option. Therefore, fuel switching did not occur.

Table 2.1. Energy Savings by Measure

\begin{tabular}{||l|r|r|}
\hline \multirow{2}{*}{ Measure } & \multicolumn{2}{|c|}{ Energy Savings (kWh/yr) } \\
\cline { 2 - 3 } & Completion Reports & Impact Evaluation \\
\hline Building 40-05 & & \\
Warehouse/production area controls & 929,155 & $1,362,760$ \\
Office area lighting & 97,551 & 97,551 \\
Office area controls & 19,219 & 19,219 \\
Restroom/cafeteria controls & 18,790 & 18,790 \\
Restroom/cafeteria lighting & 25,066 & 25,066 \\
Parking lot lighting & 532,276 & 578,160 \\
Total & $1,662,057$ & $2,101,546$ \\
\hline
\end{tabular}




\subsection{Impacts to the Firm}

If the projects improved the productivity of the process, did the firm then increase output of the process to take advantage of the productivity improvement? Did the change in output result in a net increase or decrease in energy used by the process? Did the change in output cause changes in output at the firm's other plants in the region?

Because these projects affected only the lighting system, no measurable productivity improvements were noted. Boeing has other plants in the region; however, no impacts will occur at these plants as a result of these projects.

\subsection{Impacts to the Utility}

What is the net impact to the serving utility in terms of electrical energy consumption (in kilowatt-hours) from implementing the projects?

Because the projects had no cogeneration or other complicating factors, all of the energy savings from these projects will be reflected in reduced load at the utility, Snohomish County Public Utility District. The net impact to the serving utility from this project is an electrical load reduction of $2,101,546 \mathrm{kWh} / \mathrm{yr}$.

\subsection{Real Levelized Costs}

What are the real levelized costs of the projects from the perspectives of Bonneville and the region?

Real levelized annual costs are used to compare the attractiveness of various projects or investment alternatives. The levelized cost is the annual cost that would be incurred over the life of a project, accounting for the time value of money (see Appendix A for complete definitions and formula). Levelized costs provide a single figure of merit for comparing energy conservation alternatives. In addition, levelized costs can be used to compare conservation projects with options for new generating capacity and to optimize the ranking of these options. Levelized costs are calculated from the perspectives of Bonneville and the region (Bonneville and Boeing combined). 
In the industrial sector, it is not possible to accurately predict the life of a project, because any number of external factors could cause the project to have longer or shorter life than expected when it is installed. To allow comparisons of levelized costs among projects installed under the E\$P, all projects are assumed by PNL (for evaluation purposes) to have a life of 15 years. Even though some projects will have longer or shorter lives, 15 years is considered a conservative, but likely, life for typical projects in the industrial sector.

\subsubsection{Bonneville Perspective}

To determine the real levelized costs to Bonneville and to the region, we must know the project costs (acquisition payment, capital costs, etc.) and the energy savings, and we must assume a discount rate and project life. With a combined energy savings of 2,101,546 kWh/yr, the project's combined levelized cost from Bonneville's perspective is 6.4 mills $/ \mathrm{kWh}$ (in 1993 dollars). For the individual projects, the levelized costs are 4.1 mills $/ \mathrm{kWh}$ for the Building 40-05 and $12.5 \mathrm{mills} / \mathrm{kWh}$ for the parking lot projects (see Appendix A). Bonneville's combined levelized cost decreases to $6.0 \mathrm{~m}: 1 / \mathrm{s} / \mathrm{kWh}$ when transmission and distribution losses are considered. The project's levelized costs decrease to 3.8 mills $/ \mathrm{kWh}$ for the Building 40-05 project and $11.6 \mathrm{mills} / \mathrm{kWh}$ for the parking lot project when transmission and distribution losses are considered. Including these losses allows for the comparison of conservation resources with generation, which is measured at the point of production rather than at the site of the end user (point of delivery).

The levelized costs calculated in this impact evaluation include the acquisition payment by Bonneville as well as Bonneville's estimated administrative and evaluation costs associated with this project.

\subsubsection{Regional Perspective}

To calculate the real levelized cost to the region, the costs to Bonneville and Boeing are combined. The acquisition payment by Bonneville is included as a cost to Bonneville and as a reduction in cost to Boeing. This approach is taken because the acquisition payment has federal income tax consequences for the company and, therefore, is not a net-zero cost to the region. In other words, Boeing paid income taxes on its acquisition payment from Bonneville, which has the effect of increasing the region's levelized cost.

The combined calculated, real, levelized costs to the region for acquiring annual energy savings of $2,101,546 \mathrm{kWh}$ are $19.0 \mathrm{mills} / \mathrm{kWh}$ saved $(8.0 \mathrm{mills} / \mathrm{kWh}$ for the Building 40-05 project and 48.0 mills $/ \mathrm{kWh}$ for the parking lot project). Inciuding transmission and distribution losses, the 
combined levelized cost decreases to $17.7 \mathrm{mills} / \mathrm{kWh}$ saved $(7.4 \mathrm{mills} / \mathrm{kWh}$ for the Building $40-05$ project and 44.7 mills $/ \mathrm{kWh}$ for the parking lot project). The levelized costs are summarized in Table 2.2.

Table 2.2. Levelized Energy Cost (1993 mills/kWh)

\begin{tabular}{|l|c|c|c|}
\hline & Building 40-05 & Parking Lot & Combined \\
\hline Bonneville & 4.1 & 12.5 & 6.4 \\
Regional & 8.0 & 48.0 & 19.0 \\
Bonneville with trans./dist. & 3.8 & 11.6 & 6.0 \\
Regional with trans./dist. & 7.4 & 44.7 & 17.7 \\
\hline
\end{tabular}

\subsection{Impact Attributable to E\$P}

\section{How much of the projects' impact can be attributed to the E\$P?}

Boeing uses simple payback to select plant improvement projects, with a payback of less than 2 years typically required for project implementation. When the Building 40-05 project was proposed to Bonneville, it was expected to cost $\$ 87,137$ and result in an electrical savings of $\$ 23,921 / \mathrm{yr}$ (based on estimated energy savings of $1,089,781 \mathrm{kWh} / \mathrm{yr}$ ), for a simple payback of 3.6 years without an acquisition payment from Bonneville. With the expected acquisition payment of $\$ 64,704$, the simple payback was reduced to 0.85 years. This met Boeing's criterion for this project, and the project was approved.

When the parking lot project was proposed to Bonneville, it was expected to cost $\$ 130,000$ and result in an electrical savings of $\$ 11,704 / \mathrm{yr}$ (based on estimated energy savings of $532,000 \mathrm{kWh} / \mathrm{yr}$ ), for a simple payback of 11.1 years without the acquisition payment from Bonneville. With the expected payment of $\$ 75,849$, the simple payback was reduced to 4.6 years. Although this project was expected to have a payback length longer than Boeing's criterion, the project was approved.

During our site visit and interview, we were told that the acquisition payments from Bonneville were instrumental in Boeing's decision to implement these two projects. Furthermore, we were told that the projects would not have been implemented without the acquisition payments. Considering 
these facts, we conclude that these projects would not have been implemented without the acquisition paysnents from Bonneville and that all of the projects' impact can be attributed to the E\$P. 


\subsection{References}

Spanner, G. E., D. R. Brown, D. R. Dixon, B. A. Garrett, R. W. Reilly, J. M. Roop, and S. A. Weakley. 1988. Potential Techniques for Evaluating the Impact of Industrial Energy Conservation Projects under Bonneville's Energy \$avings Plan. Letter Report. PNL-6628, Pacific Northwest Laboratory, Richland, Washington. 
Appendix A

Financial Evaluation Details 


\section{Appendix A}

\section{Financial Evaluation Details}

\section{A.1 Definitions}

Real Levelized Cost - A single figure of merit that expresses the cost per unit of benefit (in this case, energy savings), accounting for the time value of money. This annualized cost (not the "adjusted system real levelized cost") would be constant over the entire project life. An infinite number of cash flow scenarios (costs incurred at different times in the project life) could result in the same annualized cost.

Real Levelized Cost to Bonneville Power Administration (Bonneville) - The annualized costs to Bonneville, direct and indirect, per unit of energy saved by the energy conservation project. Costs included are the acquisition payment and the program administrative costs, as well as the costs to evaluate the impact of these projects.

Real Levelized Cost to the Region - The sum of annualized costs to Bonneville and Boeing per unit of energy saved by the energy conservation projects. This would include the same costs to Bonneville as listed above, as well as the initial capital and ongoing incremental production costs to the firm. Any non-electrical savings that result from the projects are not considered in this analysis.

\section{A.2 Real Levelized Cost Formula}

$$
\begin{gathered}
\mathrm{LC}=\{[\mathrm{PVCI}+\mathrm{PVICI}+(\mathrm{PVOM}+\mathrm{PVOTE}) \bullet(1-\mathrm{itf})-\mathrm{PVD} \bullet \mathrm{itf}] \\
/(1-\mathrm{itf})\} \bullet(\mathrm{CRF} / \mathrm{AES})
\end{gathered}
$$

$$
\text { where } \begin{aligned}
\text { LC } & =\text { levelized cost (real } \$ \text { ) } \\
\text { PVCI } & =\text { present value of initial capital costs } \\
\text { PVICI } & =\text { present value of interim capital costs } \\
\text { PVOM } & =\text { present value of operating and maintenance costs } \\
\text { PVOTE } & =\text { present value of one-time expenses } \\
\text { itf } & =\text { combined state and federal income tax fraction }
\end{aligned}
$$




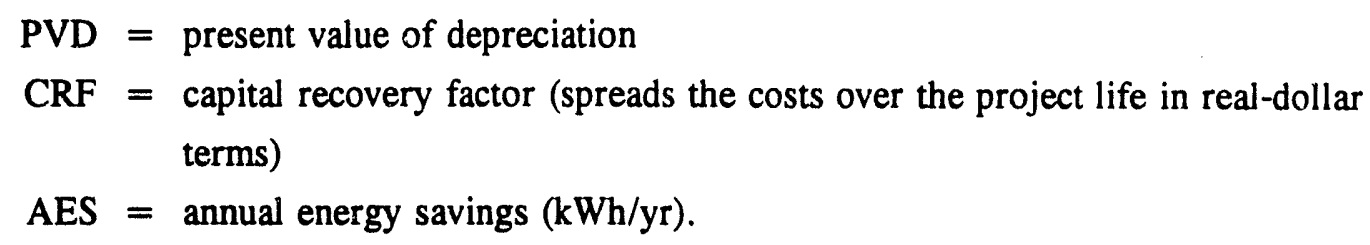

\section{A.3 General Assumptions}

The following general assumptions were made in the real levelized cost calculations:

1. All cash flows are expressed in nominal terms (with inflation) and are discounted to present value at a nominal discount rate of $7.12 \%$ (combines a real discount rate of $3.0 \%$ and an inflation rate of $4.0 \%$ ). The costs are annualized over the life of the project using the capital recovery factor at a real discount rate of $3.0 \%$, resulting in real levelized costs.

2. Annual energy savings $(\mathrm{kWh} / \mathrm{yr})$ are constant over the 15 -year life of the project. This assumes no loss in efficiency of the equipment with time.

3. Transmission and distribution losses equal $7.5 \%$, increasing the energy savings at the source (point of generation) by a corresponding $7.5 \%$.

4. In the regional cost calculation, the acquisition payment from Bonneville is treated as a cost to Bonneville and, at the same time, as a cash inflow to Boeing rather than a net zero cost. This is done because Boeing will incur a tax liability from the acquisition payment, thus incurring a net cost to the region.

\section{A.4 Bonneville Levelized Cost Calculations}

Input: one-time expenses

Building 40-05 project:

Acquisition payment paid (year 1) $=\$ 64,996$

Administrative and evaluation costs (years 0 and 1 ) $=\$ 11,000$

Tax rate

Annual energy savings

Output: levelized cost
$=0 \%$

$=1,523,386 \mathrm{kWh}$

$=4.1 \mathrm{mills} / \mathrm{kWh}$ 
Parking lot project:

Acquisition payment paid (year 1) $\quad=\$ 75,849$

Administrative and evaluation costs (years 0 and 1 ) $=\$ 12,085$

Tax rate

$=0 \%$

Annual energy savings

$=578,160 \mathrm{kWh}$

Output: levelized cost

$=12.5 \mathrm{mills} / \mathrm{kWh}$

\section{A.5 Regional Levelized Cost Calculations (Bonneville + Boeing)}

A. Boeing

Building 40-05 project:

Input: initial capital (year 0)

Equipment

$=\$ 85,512$

One-time expenses (revenues - year 1)

Acquisition payment it sived

$=(\$ 64,996)$

Tax rate

$=34 \%$

Project life

$=15$ years

Depreciation

$=0$ years

Annual energy savings

$=1,523,386 \mathrm{kWh}$

Output: levelized cost

$=3.9$ mills $/ \mathrm{kWh}$

Parking lot project:

Input: initial capital (year 0)

Equipment

$=\$ 202,000$

One-time expenses (revenues - year 1)

Acquisition payment received

$=(\$ 75,849)$

Tax rate

$=34 \%$

Project life

$=15$ years

Depreciation

$=0$ years

Annual energy savings

$=578,160 \mathrm{kWh}$

Output: levelized cost

$=35.5$ mills $/ \mathrm{kWh}$

A.3 
B. Regional levelized cost $=$ Bonneville levelized cost + Boeing levelized cost

$$
\begin{aligned}
\text { Building 40-05 project: } & =4.1 \mathrm{mills} / \mathrm{kWh}+3.9 \mathrm{mills} / \mathrm{kWh} \\
& =8.0 \mathrm{mills} / \mathrm{kWh} \\
\text { Parking lot projert: } & =12.5 \mathrm{mills} / \mathrm{kWh}+35.5 \mathrm{mills} / \mathrm{kWh} \\
& =48.0 \mathrm{mills} / \mathrm{kWh}
\end{aligned}
$$

\section{A.6 Levelized Costs Allowing for Transmission and Distribution Losses}

Input: transmission and distribution losses $=7.5 \%$

Bonneville levelized cost:

Building 40-05 project $=4.1$ mills $/ \mathrm{kWh} / 1.075=3.8 \mathrm{mills} / \mathrm{kWh}$

Parking lot project $\quad=12.5 \mathrm{mills} / \mathrm{kWh} / 1.075=11.6 \mathrm{mills} / \mathrm{kWh}$

Regional levelized cost:

Building 40-05 project $=8.0$ mills $/ \mathrm{kWh} / 1.075=7.4 \mathrm{mills} / \mathrm{kWh}$

Parking lot project $\quad=48.0$ mills $/ \mathrm{kWh} / 1.075=44.7 \mathrm{mills} / \mathrm{kWh}$ 
Appendix B

Cover Sheets From Boeing's Project Proposals 


\section{Cover Sheet}

\section{I'nĭ̀et}

Project Title Replace Pole Iights

Technologies: Iiahting

Confidential or Propriecary information: $\square$ Yes No
Caregorically Excluded: (See Artachment 2, Program Description Bookler)

Yes No

X]

\&

\begin{tabular}{|c|c|c|}
\hline Industry & Aircraft Manufacturing & $\begin{array}{l}\text { Coneace: } \\
\text { Same as Industry conract }\end{array}$ \\
\hline Name: & Boeing Comnercial Airplane & $\square$ Utiliry Representative, if utility-operated program \\
\hline Talle- & $\begin{array}{l}\text { Group } \\
\text { Everett Division }\end{array}$ & Name: Craig Poundstone \\
\hline Address: & $\begin{array}{l}\text { P.O. BOx } 3707 \\
\text { M/S OAf-24 }\end{array}$ & Phane: $\quad 342-7354$ \\
\hline City: & Seattle & SIC Code: \\
\hline Stare: & WA Zip: $98124-2207$ & Uriliry Service Area: Snohanish County PUD \#I \\
\hline Atrention: & : Craig poundstone & Utility-Operated Program: $\square$ Yes $\square$ No \\
\hline II. Project: & Summary & \\
\hline
\end{tabular}

A Brief Project(s) Description:

Droject will replace all existing parking lot and yard lighting with new energy efficient lighting fixtures.

\section{JiI. Estimated Enerhy Strings and Costs}

Average Annual Energy Savings:

$$
532,000 \mathrm{kwh} / \mathrm{yr}
$$

Estimated Incentive:

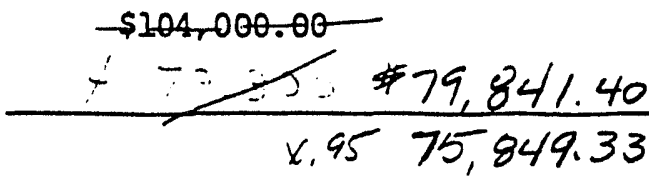

Tocal Project Cost:

$$
\$ 130,000.00
$$

B. 1

Continue on back, if necessary 


\section{CoverSheet}

I. Project

Project Tide:

Technologies:

LIG.HTINE
Categorically Excluded: (See Atcachment 2, Program Description Booklet)

Confidential or Proprietary Information: $\square$ Yes $\square$ No

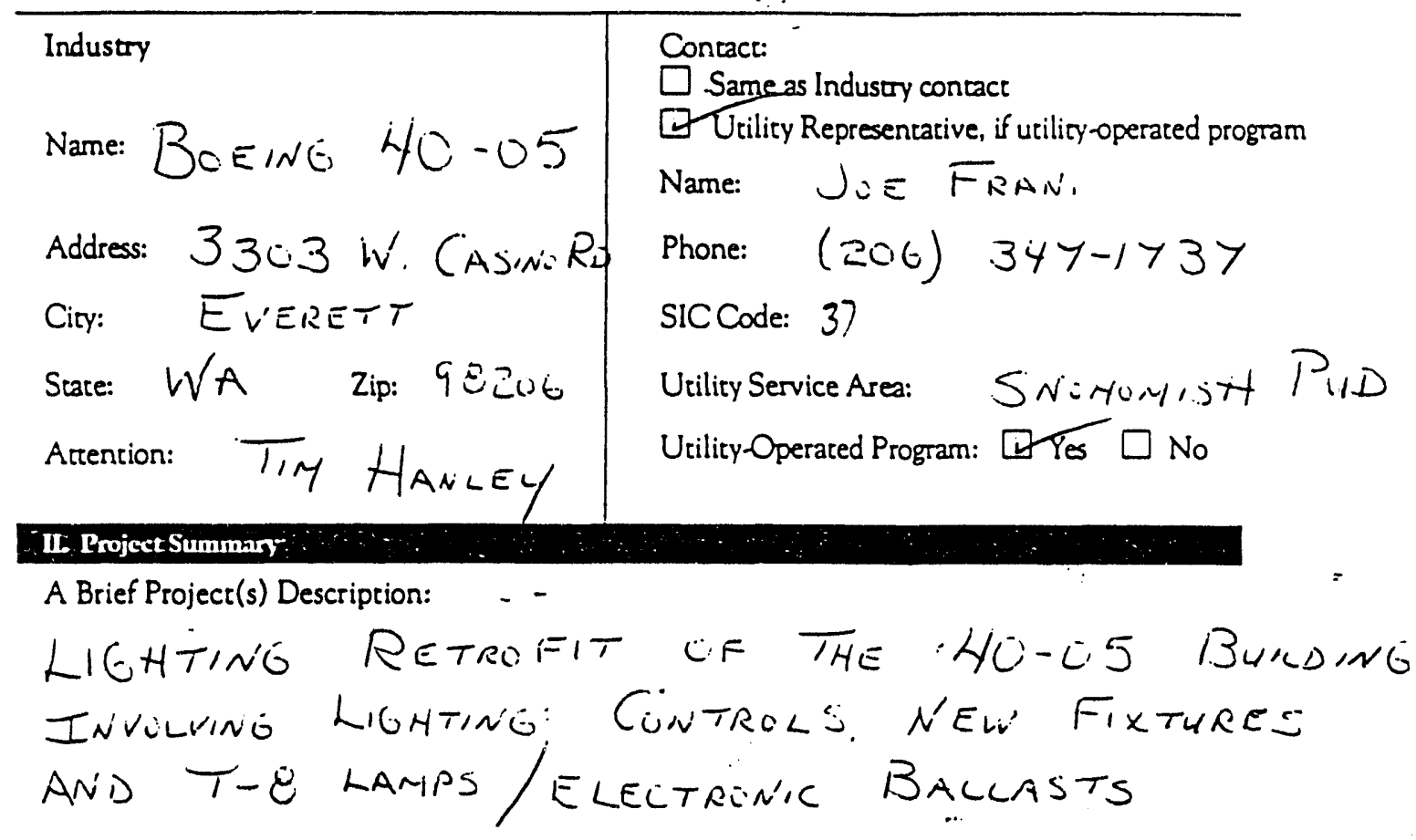

III. Estimated Enerty; Savings and Costs

Average Annual Energy Savings:

$1,089,730$

Estimated Incentive:

$$
\$ 64,704.19
$$

Total Project Cost:

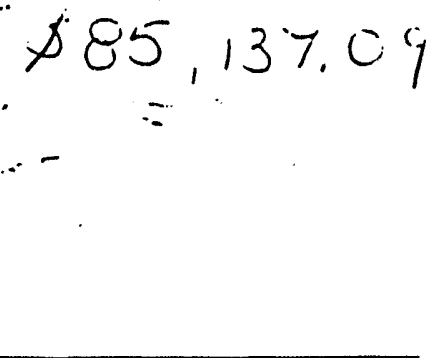

Continuc on back, if necessary 


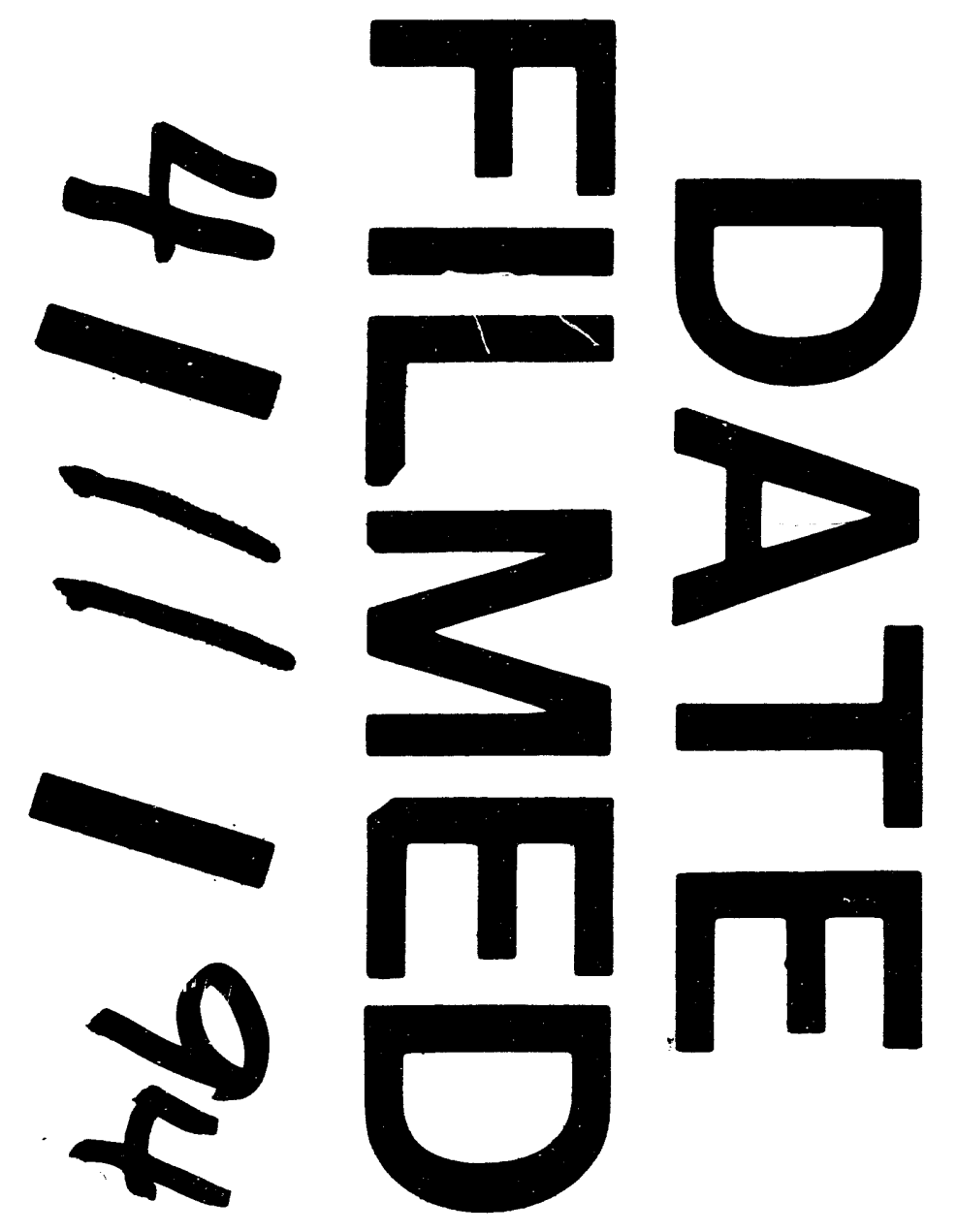


